\title{
A RESISTÊNCIA AO AUTORITARISMO PATRIARCAL E POLÍTICO EM ARMADILHA PARA LAMARTINE DE CARLOS \& CARLOS SUSSEKIND
}

\author{
POR \\ Rex P. Nielson \\ Brigham Young University
}

Disse-lhe, todavia, que a vida em sociedade impunha
restrições que tinham de ser respeitadas, custasse o que
custasse. Ele pareceu concordar.
Carlos \& Carlos Sussekind, Armadilha para Lamartine

Em agosto de 2001, depois de mais de 25 anos de debate, o Congresso Nacional brasileiro aprovou a substituição do há muito ultrapassado código civil de 1916, código esse altamente conservador e discriminatório. O novo código civil, que entrou em vigor em 11 de janeiro de 2003, atualizou numerosas disposições legais referentes à família, à propriedade, ao Estado e às leis contratuais. Enquanto o antigo código sancionava a autoridade masculina no lar, no novo código as antigas leis que regulamentavam as relações entre homem e mulher foram claramente reformuladas de modo a promover os direitos da mulher e a modificar o conceito de casamento e família de forma a proteger os direitos da mulher e das crianças. Pela primeira vez o código foi redigido com terminologia neutra (empregou-se "pessoa" em lugar de "homem"). A definição legal de casamento foi alterada de forma a tratar marido e mulher como parceiros igualitários. O mesmo aconteceu com os termos que regem o divórcio, legalizado apenas em 1978: foram alterados de modo a garantir direitos iguais de custódia dos filhos e partilha de bens. O novo código inclui muitas outras medidas promotoras de igualdade nas questões de direito familiar, como por exemplo, direito sucessório, maioridade e adoção, entre outras (Noonan e Almeida 99). ${ }^{1}$ Em suma, essas mudanças efetivamente deram fim ao poder unilateral do pai.

Apesar dos avanços introduzidos no novo código civil, a lei recebeu críticas por parte de alguns, por não ser suficientemente progressista na defesa dos direitos individuais.

\footnotetext{
Para uma análise mais completa das mudanças introduzidas pelo novo Código Civil brasileiro com relação à família e ao casamento ver a International Encyclopedia of Sexuality, verbete "Brazil", redigido por Sérgio Luiz Gonçalves de Freitas, com a colaboração de Elí Fernandes de Oliveira e Lourenço Stélio Rega, atualizado e comentado por Raymond J. Noonan, Sandra Almeida e Luciane Raibin.
} 
Mala Htun e Timothy Power, por exemplo, em seu excelente estudo avaliativo do código civil, mencionam um "lingering conservatism" (conservadorismo persistente) na lei brasileira (83-104). Outros questionaram a demora dessas alterações, tendo em vista que as primeiras modificações do código foram propostas em 1972 por Miguel Reale, renomado jurista brasileiro, e foram formalmente iniciadas em 1975. As deliberações no Congresso, que levaram à revisão do código em 2001, desencadearam um período de acalorada controvérsia na imprensa, que revelou uma postura moral arraigada, o que levou os sociólogos Gizlene Neder e Gisálio Cerqueira Filho a indagar:

Em que medida o atraso na aprovação do código civil é um sintoma de permanências de uma cultura política (e jurídica) fortemente assentada em concepções tomistas e absolutistas sobre o poder, a hierarquia e a obediência? De que forma a extensão do pátrio poder, tal como o formulado nas Ordenações do Reino, perpetua um modelo de família holístico, extenso, onde o paterfamilias é plenipotente e a idéia de indivíduo é muito tênue? ("Os filhos da lei” 113)

Assim como Htun e Power mencionam esse "conservadorismo persistente", Neder e Cerqueira Filho comentam a "permanência" de uma política cultural alicerçada em concepções absolutas de poder, hierarquia e obediência. Estes últimos autores sugerem que a resistência à ratificação do novo código civil deve ser vista como decorrente de condições históricas subjacentes e vão mais longe: argumentam que muitos dos problemas sociais que o Brasil enfrenta hoje (inclusive o da prostituição infantil, abuso sexual, estupro e violência doméstica) não podem ser resolvidos a menos que se tenha um entendimento claro do contexto histórico e cultural do país, ou seja, de seu "processo histórico-cultural subjacente" (Neder e Cerqueira Filho 113). Esse contexto se inicia com os engenhos do período colonial brasileiro.

É impossível salientar demais a importância dos engenhos no Brasil colonial e a persistência dessa influência na cultura brasileira. A família colonial deu origem a uma hierarquia e rede de relacionamentos sociais tão influentes que ainda hoje se veem seus efeitos na esfera política, social e cultural do Brasil. O patriarca da família, o "senhor do engenho", supervisionava todos os aspectos da vida no engenho: tanto as atividades econômicas como a produção agrícola, chegando até a ditar a lei e impor punições. Neder e Cerqueira Filho escrevem:

Temos, portanto, um universo patriarcal onde o paterfamilias era investido de autoridade e responsabilidade sobre todos os membros de sua casa, inclusive os empregados. Dependia de cada um prestar a obediência devida de acordo com o seu lugar-fosse como esposa ou como filho, como agregados ou escravos, como manda uma ordem fortemente hierarquizada. [...] A autoridade masculina estendia-se a todos os membros da casa. [...] Todos sujeitavam-se à autoridade do senhor. (122)

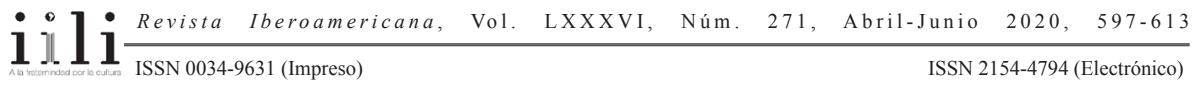


A família patriarcal colonial estruturada nos moldes do engenho impunha sua hierarquia ao governo das relações sociais não só aos membros do núcleo familiar, mas também a um círculo de dependentes periféricos muito mais amplo e difícil de definir, constituído por escravos, agregados, empregados, amantes, filhos ilegítimos, etc.

No final do século XIX e início do XX, a estrutura da família colonial passou por rápidas mudanças, e as famílias perderam sua centralidade política e econômica devido aos efeitos da urbanização e da industrialização. As redes familiares gradualmente perderam seu poder político, mas os conceitos de família e lar continuam a afetar a política e a sociedade. Roberto DaMatta assevera que, no Brasil, a família não deve ser vista como mera unidade social, mas sim como um valor. Ele afirma: "Família não é apenas uma instituição social capaz de ser individualizada, mas constitui também e principalmente um valor. [...] Assim, a família é um grupo social, bem como uma rede de relações" (125). Ele argumenta que a sociedade brasileira favorece um tipo específico de relacionamento social (ou forma como as pessoas relacionam-se umas com as outras em sociedade) que foi institucionalizado na família. Ele conclui: "Entre nós, a família é tudo e vale por tudo. Aqui, ela-embebe-a própria sociedade com suas regras, a tal ponto que todo político sabe que a melhor imagem de tranquilidade para o país é o grande paradigma da nação como uma família, onde o povo é a prole e os pais são os governantes" (136). Sendo assim, para interpretarem-se e efetuarem-se mudanças sociais hoje, é essencial entender os valores familiares brasileiros.

\section{REAÇÕES LITERÁRIAS À ORDEM PATRIARCAL NA POLÍTICA DA DÉCADA DE 1970}

Ainda que não se possa negar a natureza patriarcal da família brasileira, na seção anterior deste artigo, discorremos sobre a família brasileira para indicar a relação crucial entre a estrutura patriarcal da família colonial, sua versão moderna, que é o núcleo familiar brasileiro, e o ambiente moral, jurídico e político brasileiro, bem como para contextualizar algumas das diversas reações literárias à ordem patriarcal na ficção brasileira contemporânea. Talvez não seja coincidência o fato de que um ano depois de Miguel Reale propor a revisão do código civil brasileiro em 1975, encontre-se uma importante reação literária à moralidade patriarcal sob forma da obra Armadilha para Lamartine (1976), de Carlos \& Carlos Sussekind.

Armadilha para Lamartine foi publicada no auge da ditadura militar brasileira, que assumiu o controle do país em 1964 e só terminou em 1985. Em dezembro de 1968, a intolerância do governo militar a qualquer forma de oposição política resultou no infame Ato Institucional $\mathrm{n}^{\circ} 5$, ou AI-5, que suspendia o direito a habeas corpus. Com o AI-5, "aumentaram as perseguições políticas, as prisões arbitrárias, a tortura, os assassinatos e os desaparecimentos" (Guia de Direitos Humanos 24). A essa medida, seguiu-se uma série de decretos repressivos que limitava as liberdades civis e reforçava a autoridade do Estado.

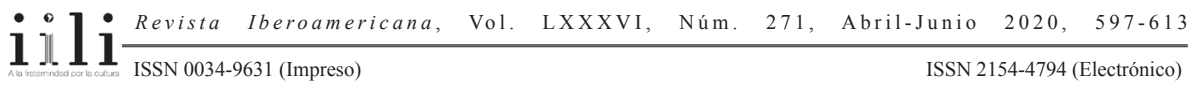


Com o aumento das mortes, desaparecimentos, prisões e tortura, os familiares dessas pessoas desaparecidas ou mortas começaram a organizar-se para fazer denúncias e protestar contra o governo, contra as torturas e contra as terríveis condições em que os prisioneiros políticos eram mantidos. Ainda assim, em geral, a maioria da população tinha pouco conhecimento dessas ocorrências, já que os meios de comunicação, ou seja, os jornais, a televisão e o cinema, eram monitorados de perto e censurados. Em nome da purificação do país e da manutenção da ordem nacional, o governo militar adotou medidas extremas, muitas vezes violentas. Os jornais e outros meios de comunicação não podiam publicar os atos de autoritarismo e violência do Estado, e a maioria desses meios de comunicação praticava um tipo de "autocensura" (Skidmore 64) para evitar que o governo tirasse de circulação toda uma edição de um jornal ou revista. O mesmo ocorria com os estúdios de cinema, que, devido aos custos de produção, não podiam correr o risco de ter um filme tirado do mercado no último minuto.

Durante a década de 1970, os líderes do governo preocupavam-se principalmente com o cinema e os jornais, ou seja, com os meios de comunicação capazes de alcançar o maior público. Ainda assim, o medo da censura inquestionavelmente fez-se sentir também na produção literária da época. Alguns críticos dizem que essa época representou um "vazio cultural”, termo cunhado por Zuenir Ventura, jornalista da revista Visão, para descrever, de seu ponto de vista, os efeitos da censura na produção cultural brasileira. Contudo, muitos críticos discordam. Flora Süssekind, por exemplo, em Literatura e vida literária, argumenta que a literatura daquele período conseguiu "preencher as lacunas de informação dos jornais e dos veículos de massa" (37). Ela dá a entender que a censura aos meios de comunicação por parte do governo fomentou importantes reações literárias à ditadura, e enquadra essas reações em duas categorias: a documental e a do realismo mágico (alegórica). Tânia Pellegrini faz uma afirmação semelhante, ao sugerir que a censura deve ser vista não como força primária a impulsionar a transformação cultural e inovação estética, mas como parte de um complexo mecanismo social que resultou em novas formas de produção literária que se empenharam em documentar as realidades políticas do período como forma de resistência à repressão política.

Para os cidadãos das classes média e alta, a ficção documental e realista serviu para preencher a lacuna de informações históricas por testemunharem a realidade que era então censurada nos meios jornalísticos, e, na década de 1970, o que se viu foi o surgimento de diversos escritores engajados na crítica social e política: $O$ caso Morel (1973) e Feliz Ano Novo (1975) de Rubem Fonseca, Incidente em Antares (1971) de Érico Verissimo, Aracelli, meu amor (1976) de José Louzeiro, Bar Don Juan (1971) de Antônio Callado, Zero (1974) de Ignácio de Loyola Brandão, As meninas (1973) de Lygia Fagundes Telles, e A festa (1976) de Ivan Ângelo. Contudo, salta aos olhos o fato de o romance Armadilha para Lamartine ter sido deixado inteiramente fora das listas de obras de ficção política. A maioria dos críticos literários não considera

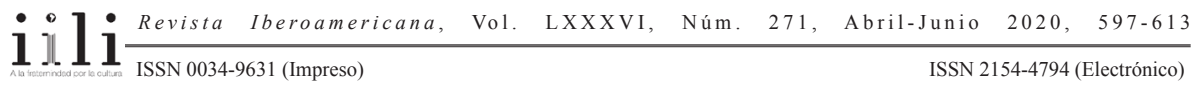


Armadilha para Lamartine como parte do corpus das principais obras da literatura de resistência e de protesto contra a ditadura. Talvez isso se deva em parte ao fato de que esse romance não se enquadra facilmente nos gêneros descritos por Flora Süssekind: ele não documenta realisticamente a violência e a opressão, que poderiam ser censuradas na imprensa, e certamente está longe de enquadrar-se no realismo mágico. O romance conta a história do que parece ser uma família carioca tipicamente burguesa e parece não ter relação alguma com o clima de agitação política da época da publicação. A obra faz apenas breve menção de alguns eventos políticos dos anos 1950 e não inclui a menor referência aos acontecimentos políticos da década de 1970. Apesar de não conter evidências documentais, o romance deveria ser incluído no corpus da literatura de resistência e lido como reação perspicaz ao momento político e histórico em que se insere.

A respeito da aceitação pública da obra, Fábio Bortolazzo Pinto afirma que "um dos pecados mais graves do livro de Sussekind parece ter sido o de passar ileso pela censura o que, ao que tudo indica, bastou para que autor e obra fossem vistos como alienados ou, no mínimo, descompromissados com o questionamento do estado autoritário" ("Autoritarismo" 5). Entretanto, a despeito da falta de contextualização histórico-cultural com a qual alguns críticos encaram Armadilha para Lamartine, a obra está repleta de impressionantes conotações políticas e deve ser lida como uma reação lúcida ao autoritarismo patriarcal do Estado, precisamente pela forma como aborda questões tais como o exercício do poder, violência, hierarquia e tensões entre a identidade individual e comunitária.

Por meio do simbolismo dos conflitos familiares, Armadilha para Lamartine explora os abusos da autoridade patriarcal. Não é de admirar que, na época, a produção literária de reação à ditadura militar com frequência, e por vezes explicitamente, identificasse o regime político autoritário com a figura paterna. A obra Armadilha para Lamartine gira em torno do relacionamento entre uma figura paterna forte e um filho que se recusa a moldar-se à imagem do pai, ou é incapaz de fazê-lo, e que, por isso mesmo, tenta escapar. O ponto central da trama é o retorno do filho que antes abandonara o lar. O enredo segue assim o modelo bíblico do filho pródigo, da história do filho que se rebela contra o pai e sai pelo mundo mas acaba por dar-se conta do quanto estava errado e retorna à casa paterna e reconcilia-se com o pai. No caso do romance, porém, esse modelo é frustrado, pois a obra toma um outro rumo e enverada pelo modelo literário oposto: o do Édipo Rei de Sófocles. O retorno do filho não leva à reconciliação, mas ao conflito e confronto. Dessa forma, o não retorno, a não reconciliação com o pai, ocorre em dois âmbitos: no âmbito do enredo, no qual o filho volta mas não se reconcilia com o pai, e também em um âmbito mais amplo, no qual o próprio romance abandona seu patente precursor literário, o filho pródigo, e envereda por sua antítese-o modelo de Édipo.

Se por um lado o romance esquadrinha as ansiedades dos filhos nas estruturas patriarcais, por outro contém exemplos impressionantes das tragédias causadas pelos

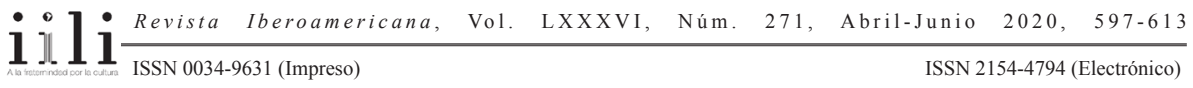


pais que não aceitam que sua família assuma outra imagem que não seja a dele. A análise da perpetuação e ruptura da tradição literária brasileira feita por Flora Süssekind em Tal Brasil, Qual Romance? parece-nos relevante a este artigo:

Àquele que não sabe respeitar os espaços culturalmente sacralizados expulsa-se da Biblioteca, como a um filho rebelde se expulsa da Casa Paterna. Do herdeiro de uma família como do aprendiz de intelectual exigem-se obediência, semelhança e continuidade. Paternidade, filiação e vinculação a uma tradição cultural apresentam grandes familiaridades. [...] E quando, ao invés do eco, ouve-se uma dúvida e percebe-se a possível ruptura de laços a rigor sagrados, a violência é idêntica. Esteja sob ameaça a herança familiar ou a tradição cultural. (29)

Posteriormente, Süssekind prossegue: "O patriarca costuma funcionar como princípio de identidade para a família” (Tal Brasil 32). Essa análise pareceu-nos de especial importância por empregar os valores da família patriarcal para descrever a cultura literária brasileira-a santidade do lar, a necessidade de hierarquia, continuidade e obediência e, acima de tudo, a situação privilegiada do pai como criador e autoridade-. Essa imagem patriarcal e os valores nela implícitos são exatamente o tema de Armadilha para Lamartine. No momento histórico em que a imagem do Brasil era estritamente controlada pelos agentes do governo visando à preservação do quadro em que a nação é comparável a uma família tranquila, esse romance revela a tragédia de uma estrutura familiar estreita, que exige de seus membros fidelidade e obediência até mesmo obsessivas, não se admitindo nenhum tipo de identidade a não ser aquela decretada pela autoridade patriarcal.

\section{A representaÇão do MUNDO PATriarcal EM ARMadilHa PARA LAMARTine}

Armadilha para Lamartine revela a forma como o discurso patriarcal molda a realidade. O romance tem por tema a forma como as estruturas narrativas representam o mundo, quem é representado e quem não é, bem como a autoridade que controla a realidade. A obra narra a história de uma família, e essa história pode ser-nos até familiar, pois é a história de um pai devotado que tenta apegar-se à família em meio às transformações desta e à crescente frustração e impaciência do filho, que quer sair da sombra do pai. Ambientado na cena urbana do Rio de Janeiro, em meio a uma família culta de classe média alta, o romance examina um mundo doméstico fechado, isolado e opressivo, estritamente organizado e governado pela lei patriarcal. Armadilha para Lamartine capta as manifestações do mundo doméstico burguês: "O mundo familiar burguês, isto é, a família burguesa, é um mundo em si mesmo, que não tem grandes laços com a sociedade inclusive; é auto-suficiente, socialmente falando, e isolada. Os membros da família não conversam senão sobre coisas banais e sobre a educação

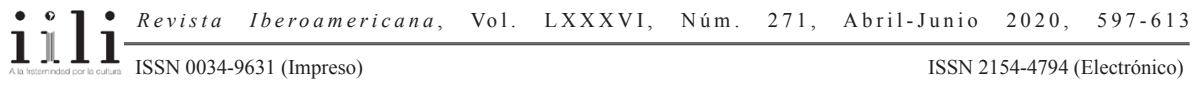


dos filhos" (D'Incao 67). Como observa a socióloga Maria Angela D'Incao, a falta de comunicação verdadeira, a falta de diálogo, é resultado da natureza isolada (e acrescentaríamos, patriarcal) da família burguesa.

A despeito da ausência de referências explícitas aos acontecimentos políticos de sua época, os anos 1970, o romance aborda as raízes da política autoritária que permeiam a cultura brasileira. Como afirma Fabio Bortolazzo Pinto: "Um exame atento do livro porém, revela que seu poder de questionamento do autoritarismo, em todos os níveis, vai muito além do que se podia conceber na época de seu surgimento" ("Autoritarismo" 5). Luciano Sousa faz afirmação semelhante ao escrever que "uma leitura mais cuidadosa nos faz ver que os questionamentos ao forte autoritarismo dos governantes, comum às obras da época, alcançam um novo patamar" (14). Tanto Pinto como Sousa fazem frente às críticas literárias que, em sua maioria, ignoram a crítica social e política contida em Armadilha para Lamartine. Em uma leitura atenta, esse romance exprime o modo como o discurso patriarcal é capaz de moldar a realidade; contudo, a obra não é mero espelho da realidade, mas sim um contradiscurso: trabalha contra a realidade.

Por meio de sua estrutura, a obra chama a atenção para a relação entre o discurso e a realidade. Logo depois da página de rosto, o leitor se depara com uma "nota" sobre os escritos coligidos sob o título geral de "Armadilha para Lamartine". Estes escritos incluem o diário de Dr. Espártaco M. (cobrindo o período de outubro de 1954 a agosto de 1955), e duas "Mensagens" escritas por Lamartine M. durante sua internação de dois meses no Sanatório Três Cruzes, um hospital psiquiátrico no Rio de Janeiro. As "mensagens" são, em geral, cheias de injúrias e ofensas aos médicos e funcionários do sanatório. De acordo com a nota inicial, Lamartine escreveu as mensagens, mas escondeu-as. Elas foram entregues ao Dr. Espártaco depois de Lamartine já haver voltado para casa e para a "normalidade".

A nota é um elemento crucial no romance, pois contém detalhes reveladores sobre os personagens. Além disso, como outros já observaram, a primeira parte da narrativa é desconcertante porque a realidade do texto, ou seja, sua cronologia ou a forma como o leitor vivencia o texto, não é condizente com o que fora anunciado na nota. A nota anuncia dois textos: o diário do Dr. Espártaco M. seguido de duas mensagens escritas do sanatório. Essa, contudo, não é a ordem com que o leitor se depara. Ao virar a página, em vez de encontrar o diário do Dr. Espártaco, o leitor se vê diante da primeira das "mensagens" que Lamartine escreveu no sanatório. Para o leitor, essa é apenas a primeira de uma série de pistas narrativas que minam sua confiança no narrador. A narrativa constantemente subverte sua própria autoridade por meio de afirmações incorretas e do fornecimento de informações falsas ao leitor quanto ao próprio material de leitura.

O fato é que essa duplicidade começa já na capa do livro, na qual a autoria é atribuída a Carlos e Carlos Sussekind. A menos que se leia uma explicação, como a 
publicada na edição mais recente da Companhia das Letras, é impossível saber qual é a relação entre um Carlos e outro (são pai e filho). ${ }^{2}$ Mesmo se sabendo disso, a questão de autoridade e autoria do texto permanece incerta. Na verdade, isso é muito provavelmente intencional, pois, apesar de o romance ter sido publicado oito anos depois da morte do pai, Carlos Sussekind filho revelou em entrevistas publicadas pouco depois da publicação que a obra era parcialmente baseada em um diário que seu pai manteve por mais de trinta anos. Essa admissão, esse pormenor biográfico, levou muitos leitores a delimitar rigidamente a autoria das duas partes distintas do romance, e a identificarem o diário do Dr. Espártaco essencialmente com os escritos do pai, só que sob um nome diferente, e a considerarem os escritos de Lamartine como sendo criação original de Carlos Filho. Outros dados biográficos reforçaram essa interpretação. Por exemplo, Luciano Sousa relata: "Carlos Sussekind filho também sofreu uma crise psicótica quando tinha 21 anos, foi internado por um período de um mês e meio, e tratado com eletrochoque, no Sanatório Botafogo que, no livro, corresponde ao Três Cruzes" (23). Esses detalhes dão ainda maior respaldo a que se atribuam as mensagens de Lamartine a Carlos filho e o diário do Dr. Espártaco a Carlos pai.

Contudo, a despeito desses dados biográficos, Carlos filho fez a seguinte observação em uma entrevista de 1976, ano da publicação do livro:

Achei realmente que tinha que fazer isso (colocar a dupla autoria): papai entrava lá com uma base muito grande, ficava então impossível eu suprimir a parte dele. Quem lê acha que a co-autoria é igual à divisão: a primeira parte seria minha e a segunda parte dele. Não é verdade. A segunda parte é bastante trabalhada, bastante inventada. (Sussekind 57)

Essa ambiguidade é um fator importante na capacidade que a narrativa tem de afirmar incorreções e conduzir o leitor por caminhos errôneos, pois, ao levantar a questão da autoria (que parte foi escrita por quem), a narrativa (e Carlos Sussekind) simultaneamente levanta a questão da autoridade: quem é o responsável pelo texto? quem é confiável e quem não é? Em última instância, o leitor precisa decidir o que é o texto que está lendo, enquanto que o romance constantemente questiona sua própria realidade.

As tensões relativas a autoria e autoridade estão em primeiro plano ao longo de todo o texto do livro. Por exemplo, a primeira "mensagem" supostamente escrita por Lamartine do sanatório intitula-se "Sobre $o$ Ataque, Jornalzinho dos Vigiados no

2 Os comentários editoriais publicados na orelha da última capa da recente edição da Companhia das Letras não só indicam que Carlos Sussekind filho adaptou os diários do pai, que cobrem um período de trinta anos e têm mais de trinta mil páginas, como também afirmam que Carlos filho é "um amável mentiroso", alertando assim o leitor antes mesmo do início da leitura.

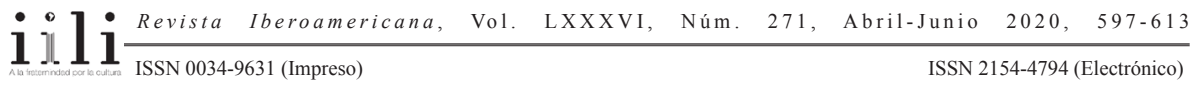


Sanatório Três Cruzes". Nela, desde o início a postura do narrador é complicada. O texto é narrado em primeira pessoa por um indivíduo que se apresenta como sendo "o ilustrador" do jornalzinho. Posteriormente o ilustrador se identifica como sendo um paciente chamado Ricardinho; contudo a "nota" que abre o livro indica que o narrador é, na verdade, Lamartine M. passando-se por Ricardinho. Com essa abertura, na qual Lamartine imita a voz de outro, o romance coloca em primeiro plano a forma como as narrativas moldam a realidade e, o que é ainda mais importante, o quanto a realidade se torna incerta quando a autoridade da narrativa é problematizada.

Na primeira mensagem, o narrador relata o impacto de um jornalzinho que circulou por pouco tempo, escrito e publicado por pacientes do sanatório. O narrador afirma que, além dele mesmo, a equipe editorial era constituída de outro paciente, chamado Mário Afonso ou simplesmente "Jornalista", que também era fundador e editor chefe do jornal, bem como por outra personagem chamada Professor Pepe, que tinha uma bela caligrafia. Só depois Lamartine passa a fazer parte da equipe. O narrador-ilustrador afirma que o nome do jornalzinho, $O$ Ataque, foi tirado de um desenho feito por ele e que se tornou a marca registrada da publicação: um índio com uma só pena na cabeça apontando uma pistola para um bandido do velho oeste, que usa um chapéu de caubói e empunha arco e flecha apontados para o índio. Cada um usa as armas do outro. O narrador-ilustrador também afirma que o índio simbolizava "o Louco", os pacientes do hospício, enquanto o bandido representava os médicos. Essa imagem tem fortes implicações quanto ao relacionamento entre pacientes e médicos: os pacientes veem-se como oprimidos e maltratados pelos médicos, a quem veem como bandidos, uns forada-lei, cuja linguagem conseguem imitar, mas sem autoridade. Obviamente, o título "o Ataque" é mais uma indicação do propósito e natureza do jornalzinho.

Somos informados que, pouco depois de ser internado no sanatório, Lamartine começou a escrever poemas místico-religioso para o jornal, mas que logo desistiu e começou a escrever o chamado "Diário da Varandola", no qual não apenas toma emprestado o título do diário de seu pai como também imita esse diário. O narrador diz que Lamartine alegava que escrevia o diário por telepatia, "abusando um pouco da nossa credulidade de doentes mentais" (13). O autoconhecimento implícito nessa declaração é mais uma manifestação da questão da autoridade e, neste caso, coloca em questão a definição de quem é louco e quem não é. Até que ponto os doentes mentais tem autoconhecimento? A mensagem se encerra com o relato do conteúdo da última edição de $O$ Ataque inclusive com uma longa descrição de uma história ilustrada na qual um dos médicos do hospital, Dr. Klossowski, foge com Inês, outra paciente no hospital. Lamartine segue os dois, mas cai em uma armadilha armada pelo Dr. Klossowski, que faz experiências com ele e o tortura com eletrochoques.

O teor dessa "mensagem" é visivelmente de grande crítica aos médicos, contudo, ao longo de todo o texto, o narrador descreve a luta pelo poder que Lamartine trava com

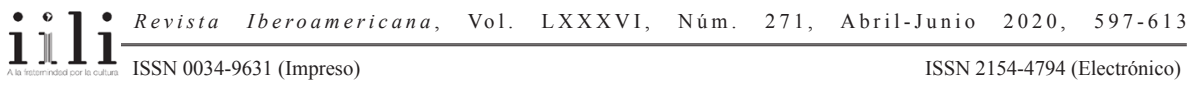


todos os que o cercam: os médicos, os outros pacientes e o pai, Dr. Espártaco. Lamartine exibe um pronunciado antagonismo diante daqueles em posição de autoridade bem como um alto grau de criatividade em sua resistência a eles. Lamartine pode parecer encontrar-se inteiramente impotente no ambiente restrito e controlado do hospital, mas mesmo assim consegue negociar a situação por meio de sua capacidade de imitação, personificação e simulação, que lhe possibilitam escrever o "diário" que publica no jornalzinho. O diário é uma imitação subversiva dos escritos do pai e, por meio dele, Lamartine conquista o respeito dos demais pacientes e passa a ter influência sobre eles. Por meio da reconstrução do diário, Lamartine demonstra que bem sabe quem ocupa a principal posição de autoridade em sua vida: o pai. O diário dá a Lamartine o distanciamento crítico que lhe permite zombar do pai, o que, por sua vez, confere a ele um status elevado aos olhos dos outros pacientes.

Além disso, nessa atmosfera de doença mental na qual os pacientes ouvem constantemente que sua visão do mundo é infundada e doentia, a clareza de estilo da escrita de Lamartine e de sua narrativa resulta em uma explicação aparentemente racional e confiável da situação. Tem-se a impressão de que o que Lamartine escreve é uma representação fiel do mundo e, contudo, não se pode ler o texto sem ter em mente a "nota" que o precede. Essa nota contextualiza os escritos de forma a essencialmente comprometer quaisquer alegações de veracidade por parte do autor: como o texto foi escrito por um doente mental durante um período de intenso tratamento psiquiátrico, sua confiabilidade permanece questionável. Por fim, quando lemos essa mensagem juntamente com o "verdadeiro" diário do Dr. Espártaco, surge um quadro mais claro das estratégias empregadas por Lamartine. Lamartine vê o diário do pai como um emblema da obsessão do pai em controlar a família. Por meio de seu diário, no qual registra e reflete sobre cada detalhe da vida de sua família, o Dr. Espártaco organiza e estrutura seu mundo. Como forma de resistência à maneira como foi representado, ou seja, como forma de afirmar sua própria autonomia e independência, Lamartine, em um ato de rebelião, reescreve o diário.

A segunda "mensagem" também gira em torno da autonomia de Lamartine para agir no ambiente restritivo do hospital. A mensagem intitulada, "Sobre a transferência de Lamartine para o pavilhão dos tranquilos", inicia-se pela alegação do narrador de que os eventos narrados são reais: "São fatos realmente ocorridos, por mais incríveis que pareçam" (22). Ele assim afirma que essa é a narrativa de fatos reais e vai além, pois revela sua fonte: "foi-me transmitido por Lamartine M." (22). Entretanto, mais uma vez essa afirmação de veracidade é suspeita, devido à nota introdutória que revela que o narrador é o próprio Lamartine e, sendo assim, que a narrativa é, na verdade, composta pelo próprio protagonista. Outra vez esse distanciamento irônico leva o leitor a questionar a autenticidade da história.

A "mensagem" concentra-se no medo intenso que Lamartine tinha da terapia por eletrochoque ministrada no hospital e em seu plano para salvar a própria vida e escapar

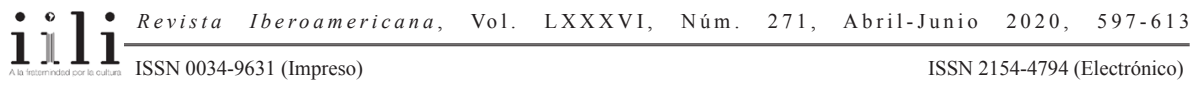


desse tratamento brutal. De acordo com o narrador, Lamartine sem querer descobre por meio de outro médico, o Dr. Klossowski, como é possível manipular os "bárbaros" (os médicos) que o tratam. A primeira fase do tratamento chama-se "demolição". Os eletrochoques são ministrados como modo de acelerar a deterioração do estado do paciente até que ele entre em uma segunda fase, chamada de "colapso total" (23). "O doente se destrói e está em condições de ser reconstruído" (23). Lamartine decide (e não fica claro até que ponto o Dr. Klossowski incentivou ou recomendou essa estratégia) fingir o "colapso total" para passar mais rápido para a fase final, a da recuperação pacífica chamada "reconstrução".

Escrevendo em retrospecto, o narrador observa que o efeito foi exatamente o desejado para "seus objetivos do momento (similar o caos)" (24). O médico de plantão vem observá-lo, mas não faz nada. Lamartine recusa-se a comer e passa a noite inteira sentado na mesma posição. Os demais pacientes começam a ficar preocupados e levam-no para o quarto. O próprio Lamartine se pergunta "o que [estaria] faltando para torná-lo um zero perfeito" (27), e então dá-se conta de que não sabe como seria um "colapso total" do ponto de vista dos médicos. Depois de passar dois dias sem comer e praticamente sem dormir, "havia esgotado todos os seus recursos de encenação, e, a essa altura, nem precisava mais fingir. Estava um trapo" (27). Ao acordar e descobrir que está sendo amarrado, imobilizado, em preparação para o tratamento de eletrochoque, ele começa a prantear, na crença que seu plano falhara. Fica ainda mais aterrorizado ao ouvir o enfermeiro dizer que "de outro modo seria fatal". Os choques são ministrados e ele é deixado em paz. Finalmente, sozinho com os companheiros de quarto, Lamartine pede um cigarro. Virando as costas para os colegas, começa a queimar-se com o cigarro. Os médicos ficam espantados com as queimaduras, e Lamartine mente e acusa os colegas de quarto de queimá-lo. Pouco depois, é removido para o Pavilhão dos Tranquilos, o que lhe parece ser uma vitória, apesar de que a mensagem se encerra com a sinistra notícia de que os eletrochoques prosseguiriam.

Assim como no texto anterior, o "plano estratégico"(23) de Lamartine fundamenta-se na falsificação dos fatos e na simulação. Desta vez, porém, as conotações políticas são muito óbvias para passarem despercebidas. O sanatório psiquiátrico é uma instituição que visa reabilitar e curar os pacientes. Os pacientes não têm direitos e são submetidos à autoridade, ao controle e às medidas de "reabilitação" impostas pelos médicos, inclusive a verdadeira tortura da dolorosa terapia de eletrochoque. Como ocorrido na reescrita do diário do Dr. Espártaco, Lamartine mina a autoridade dos médicos por meio da falsificação dos fatos. Os médicos são caracterizados como figuras paternas e, às vezes, são também claramente caracterizados como rivais de Lamartine, que consegue manipular e controlar a situação antevendo as expectativas dos detentores de autoridade quanto a ele e atendendo-as. Lamartine demonstra assim uma profunda compreensão do exercício da autoridade e essa compreensão lhe dá autonomia e possibilita sua resistência.

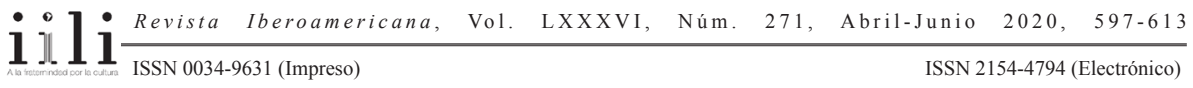


As duas "mensagens" de Lamartine são claramente atos de desafio à autoridade patriarcal. Seu tom é agressivo e, ao lançar luz sobre as atividades calculadas para minar o sistema patriarcal praticadas por Lamartine, as mensagens demonstram que ele conhece bem esse sistema. Ainda assim, as duas "mensagens" contêm mais do que sarcasmo subversivo e divertido. Ambas expressam ansiedade e temores muito reais quanto à situação perigosa em que Lamartine se encontra. Dessa forma, Lamartine, em seus escritos, lança luz sobre os reais efeitos do discurso patriarcal sobre a realidade e, ao mesmo tempo, tenta alterar e amenizar essa realidade por meio da escrita. As consequências para Lamartine são graves e o peso dessa gravidade faz-se sentir no final da segunda mensagem, no qual Lamartine fica sabendo que, apesar de ter sido bem sucedido em manipular a própria situação e conseguir a transferência para a ala de recuperação, "os choques continuariam" (29).

Assim como a nota preliminar, no início do texto, cria um contexto que mina a autoridade dos dois textos atribuídos a Lamartine, as duas "mensagens" de Lamartine que precedem o diário do Dr. Espártaco exercem essa mesma função pelo modo como moldam e condicionam a forma como lemos o diário. De certo modo, os escritos de Lamartine desdobram a narrativa do pai de maneira a revelar as inconsistências, a falta de lógica e de compreensão do discurso patriarcal. Essa narrativa incorpora uma crítica ao poder autoritário. Fabio Pinto escreve: "Os dois lados da narrativa são iguais e produzem uma visão dialética do maniqueísmo autoritário produzido pela tentativa de ordenar, controlar, ainda que através de um simples diário, a vida das pessoas à sua volta" ("Autoritarismo" 6). Sendo assim, a justaposição dos textos de Lamartine ao diário do Dr. Espártaco intensifica nossa consciência de como o diário do pai (ou seja, o discurso do pai) estrutura e ordena o mundo.

As tensões estruturais do romance se iniciam com a primeira linha do "Diário da Varandola-Gabinete": "A noite foi bem-dormida" (33). A justaposição dessa frase à frase final da segunda mensagem de Lamartine, que afirma que "os choques continuariam" (29), cria o máximo contraste possível entre a inquietação e os temores de Lamartine e a compostura calma e serena do Dr. Espártaco. A clara deliberação dos escritos do Dr. Espártaco contrastam intensamente com a astúcia, ironia e a apreensão que caracterizam as mensagens de Lamartine.

O diário do Dr. Espártaco se abre com sua descrença quanto ao comportamento ilógico do filho, que quer ir morar sozinho e ser mais independente. Escreve ele:

Que pode haver de mais ilógico do que esse drama, que estamos vivendo, de ver um filho deixar a Casa porque deseja mais liberdade, quando nunca lha estorvamos, quando (eu não tenho tempo para isso, mas Emília?) quando outra coisa não fazemos senão lhe assegurar a mais completa independência de movimentos, em todos os sentidos? A Casa não lhe fala ao coração. É um símbolo negativo. (33)

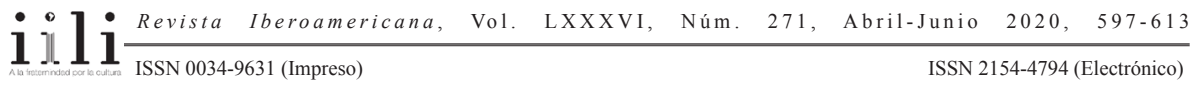


“A Casa não lhe fala ao coração. É um símbolo negativo". Aqui o lar representa a ordem simbólica. Para o Dr. Espártaco, essa ordem é fonte de identidade e estabilidade, portanto, não pode compreender que alguém considere a casa como algo que inibe a "independência de movimentos", pois, para ele, a casa representa a ordem que exatamente assegura a liberdade geral e a individual. Para o Dr. Espártaco, o lar representa uma alternativa inquestionável ao caos externo. Quando ele, na primeira página do diário pergunta "Onde há lógica na Vida?" (33), a resposta implícita é que a lógica na vida só é possível na estrutura da Casa, do Lar. A casa é o instrumento de organização do caos da vida.

Quando Lamartine anuncia sua intenção de sair de casa e ir morar com vários amigos em um apartamento alugado, em uma "república", o Dr. Espártaco imediatamente questiona essa ideia. Em âmbito pragmático, ele duvida que o filho tenha condições financeiras para tal, visto que os rapazes dependem do auxílio financeiro dos pais. Por exemplo, de Albino, um dos amigos de Lamartine, Espártaco escreve: "Quem figura no contrato? O Meyer dá-se com o Albino. Mas o Albino, economicamente, é zero. Não tem remuneração nenhuma. O ‘senhorio’ não pode ignorar isso. Será que conta com o pai? Mas, nesse caso, o pai deveria ser ouvido. E-tanto quanto estou informado-não o foi" (34). Nessa passagem, Espártaco insinua que o poder da família não vem de uma vaga noção de identidade, mas sim da inegável realidade do controle financeiro por ela exercido. A família, especialmente a família burguesa, é fonte de estabilidade financeira o que, por sua vez, cria uma relação de dependência entre filhos e pais, na qual os pais são basicamente quem tem a palavra final sobre muitas das atividades diárias dos filhos.

Em outro âmbito, porém, o Dr. Espártaco encara a saída de Lamartine como uma rejeição do modelo familiar por ele presidido e preferência por outro sistema de organização social: o sistema democrático e igualitário da "república" que, por sinal, é visto com extremo ceticismo pelo Dr. Espártaco. A seus olhos, a decisão de mudar-se tomada por Lamartine equivale à rejeição do pai. Em Armadilha para Lamartine, a parábola do filho pródigo permeia a narrativa. Espártaco identifica-se com a parábola do pai magnânimo, sábio, experiente e que, portanto, está sempre correto. Ao identificar Lamartine com o filho pródigo, ele concentra suas expectativas no retorno do filho e, ao mesmo tempo, invoca o modelo da paciência que ele crê que precisará ter para perseverar nessa "prova" de fé. A despeito dos inconvenientes que enfrenta e da irritação que sente, Espártaco acredita que, por fim, Lamartine haverá de cair em si, arrepender-se e voltar para casa.

Em outro sentido, apesar da ansiedade que o Dr. Espártaco professa sentir, quando a justapomos às duas "mensagens" de Lamartine e seu sincero temor da tortura física, as preocupações do Dr. Espártaco tornam-se triviais e sem sentido. Marguerite Harrison observa, por exemplo, que o dito "abandono" pelo filho é trivializado pelo fato de que

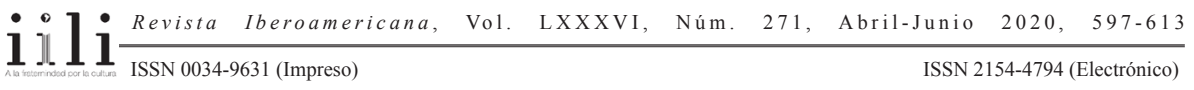


ele iria morar a apenas alguns quarteirões de distância, em um apartamento com alguns amigos (Harrison 94). Acrescentaríamos que a justaposição contextual do texto do pai com os de Lamartine leva essa trivialização ainda mais longe. Essa trivialização é empregada para subverter e ridicularizar o mito do filho pródigo e, por extensão, a autoridade de Espártaco, já que foi ele que invocou o mito.

Por outro lado, entretanto, o diário revela até que ponto os filhos do Dr. Espártaco são tolhidos, controlados e manipulados pelo mundo burguês do pai. No diário, Espártaco registra não apenas suas preocupações quanto ao local em que Lamartine vive, mas também sua inquietação quanto aos estudos, às opiniões religiosas, carreira militar, amigos, amor à vida, vestuário e até quanto à dieta do filho. Espártaco escrevia no diário diversas vezes por dia, seu mundo (a Casa) se compunha inteiramente das atividades da família, especialmente dos filhos, e era estruturado e ampliado pelo diário. De certa forma, no texto, a Casa e o diário são sinônimos. Espártaco é tanto o autor do diário como a autoridade da casa. Seus escritos deliberadamente reconstroem a realidade da família, e é importante observar tanto o que Espártaco inclui como aquilo que ele omite. Por exemplo, Espártaco relata uma discussão ocorrida certa noite, quando a família estava reunida, numa ocasião em que Danton, cunhado de Espártaco, fora fazer uma visita. Danton e Lamartine têm uma desavença quanto à arte moderna. Espártaco escreve: "Danton teria dito o que eu tantas vezes disse e digo-que a pintura moderna não nos fala à alma, não nos comunica nada, com pretensões a ser arte de iniciados, que só os 'eleitos' compreendem, mas não sabem como fazer compreender, nem se esforçam por isso" (81). Esse trecho contém uma revelação crucial: o Dr. Espártaco concorda plenamente com o argumento de Danton, ao qual, nós, os leitores não temos acesso e, sendo assim, contamos apenas com o argumento do Dr. Espártaco. Ele rejeita a pintura moderna porque ela não exprime prontamente a mensagem que alega expressar. Isso simboliza precisamente a falta de comunicação entre pai e filho. Espártaco não entende Lamartine, exceto em seus próprios termos. O pai não se esforça por ver as coisas de outro ponto de vista que não seja o da ordem e estrutura do mundo por ele criadas, ou que o criaram e que, seja como for, ele abraça e defende.

Devido à rígida visão do mundo do pai, Lamartine sente-se cada vez mais controlado e sufocado. Considerando essa atmosfera opressiva, a suposta crise psicótica de Lamartine pode ter sido igualmente fruto de uma decisão consciente para escapar ao controle do pai. A loucura dá a Lamartine a opção de viver a vida sem as restrições paternas. Para Espártaco, a loucura é a única explicação que faz sentido para o comportamento "irracional" de Lamartine (isto é, para sua decisão de sair de casa, para seu desejo de independência, sua escolha de amigos e, essencialmente para todas as decisões suas com as quais Espártaco não concorde). Algo semelhante ocorre com Lamartine que, diante do autoritarismo que impera em sua vida familiar, opta pela loucura como forma de participar de um mundo que não se enquadre nas expectativas da família.

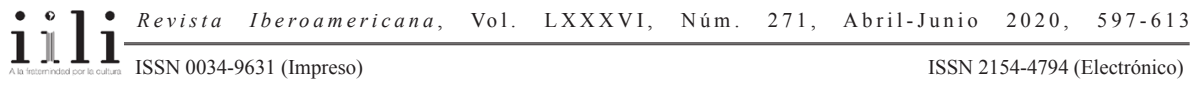


As experiências que Lamartine vivencia em casa e no sanatório abrem-nos uma perspectiva para os acontecimentos sociais e políticos ocorridos em meados da década de 1970. Suas experiências dão-nos pistas sobre como a ditadura lidou com os radicais e dissidentes e porque o fez: o tratamento bruto era necessário porque esses "filhos do Estado" agiam como insanos. O pai só consegue entender as ações do filho como frutos da loucura; contudo, o texto mina o ponto de vista e a autoridade paternos pois subverte o discurso paterno ao reescrevê-lo, ironizá-lo e zombar dele.

\section{CONCLusÕES}

Por meio da revelação, repetição e rearticulação da voz do pai, Carlos e Carlos Sussekind apontam as falhas, os abusos e limites da autoridade patriarcal. Lançam luz sobre as coisas que escapam ao controle dessa autoridade, enquanto, possivelmente, alertam para o perigo de trocar-se o modelo autoritário paterno por outro modelo autoritário (o do filho). Em outras palavras, apesar de, na obra, o filho ter resistido ao modelo autoritário do pai, continua aberta a questão de se ele será capaz de verdadeiramente mudar o modelo patriarcal ou se meramente suplantará o patriarca.

Contudo, é inquestionável que Armadilha para Lamartine é uma reação à imagem tradicional da família brasileira. Esta imagem e as ansieades provocadas por ela são perceptíveis na obra de José de Alencar, Machado de Assis, Mário de Andrade, Raquel de Queirós, Graciliano Ramos, José Lins do Rêgo, Clarice Lispector e Lygia Fagundes Telles, entre muitos outros. Além disso, não se pode ignorar o contexto social e histórico desse romance, já que ele se contrapõe a um momento político específico que é também o fruto de uma longa tradição de autoridade e poder, tanto na estrutura familiar como na do Estado. Essas duas tradições, a tradição literária de emprego de modelos familiares e a tradição sócio-política de exercício da autoridade, estão profundamente entrelaçadas e, portanto, é muito útil perceber como esses textos se situam na interseção dessas duas tradições, considerando o diálogo entre elas travado na obra.

A Família e o Estado. Armadilha para Lamartine é um romance importante, não só pela forma como reage a uma realidade sócio-política específica (e isso em si já é benéfico e revelador), mas de modo geral, pela maneira como pondera as formas pelas quais cada indivíduo negocia as obrigações, restrições, deveres e exigências familiares que, em última instância, assumem a dimensão de pressão comunitária, nacional e cívica sobre ele exercidas. Ainda assim, pode haver quem indague por que colocar esse romance em foco em vez de outros textos que comentem a ditadura mais abertamente. Por mais que $A$ festa, Feliz ano novo e outros textos censurados durante a ditadura abordem aspectos específicos da atividade, opressão, abuso e resistência política, bem como os protestos da época da ditadura, a leitura de Armadilha para Lamartine como obra expressamente voltada para a discussão da autoridade patriarcal revela o paralelo

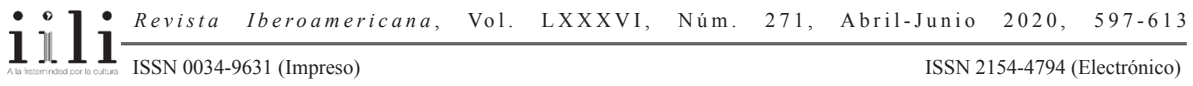


existente entre a tensão entre o indivíduo e as pessoas em posição de autoridade por um lado e, por outro, a estrutura familiar e a estrutura social brasileiras. Assim, o romance demonstra a forma em que a família mantem sua autoridade e estrutura e ao mesmo tempo denuncia os efeitos negativos desta autoridade e estrutura sobre o indivíduo.

\section{OBRAS CITADAS}

DaMatta, Roberto. “A família como valor: considerações não-familiares sobre a família à brasileira." Pensando a Família no Brasil: da Colônia à Modernidade. Angela Mendes de Almeida, Maria José Carnerio e Silvana Gonçalves de Paula, orgs. Rio de Janeiro: Espaço e Tempo, 1987. 115-36.

D’Incao, Maria Angela. "Amor romântico e família burguesa". Amor e Família no Brasil. Maria Angela D’Incao e Fernando Torres Londoño, orgs. São Paulo: Contexto, 1989. 57-71.

Criado, Alex, org. Guia de Direitos Humanos: Fontes para jornalistas. São Paulo: Cortez, 2003.

Harrison, Marguerite Itamar. "Filial Failures: Family Discourse in Contemporary Brazilian Fiction.” Tesis de doctorado. Brown University, 1995.

Htun, Mala, e Timothy J. Power. "Gender, Parties, and Support for Equal Rights in the Brazilian Congress." Latin American Politics \& Society 48/4 (2006): 83-104.

Neder, Gizlene, e Gisálio Cerqueira Filho. "Os filhos da lei”. Revisa Brasileira de Ciências Sociais 16/45 (2001): 113-25.

Noonan, Raymond J. e Robert T. Francoeur, eds. "Brazil." Continuum Complete International Encyclopedia of Sexuality. Oxford: Oxford UP, 2004. 98-112.

Pellegrini, Tânia. Gavetas vazias: ficção e política nos anos 70. Campinas: Mercado de Letras, 1996.

Pinto, Fabio Bortolazzo. "Fusão, apagamento, assimetria e representação em Armadilha para Lamartine de Carlos \& Carlos Sussekind.”.Revista Letras 64 (2004): 103-23.

"Autoritarismo e patrulhamento: sobre a recepção de Armadilha para Lamartine, de Carlos \& Carlos Sussekind pela censura e pela crítica literária nos anos 70". Revista Eletrônica de Crítica e Teoria de Literaturas 1/1 (2005): 1-6.

Skidmore, Thomas E. Brazil: Five Centuries of Change. Oxford: Oxford UP, 1999.

Sousa, Luciano Neves de. "Os rastros do silêncio: O diálogo entre literatura e loucura em Armadilha para Lamartine, de Carlos \& Carlos Sussekind”. Tesis de mestrado. Universidade Federal de Minas Gerais, 2007.

Sussekind, Carlos. "Para conseguir suportar essa tonteira". Entrevista por Ana Cristina César. Opinião (10 sept. 1976): 57.

\& Carlos. Armadilha para Lamartine. Rio de Janeiro: Labor, 1976.

Süssekind, Flora. Literatura e vida literária: polêmicas, diários e retratos. Rio de Janeiro: Jorge Zahar, 1985.

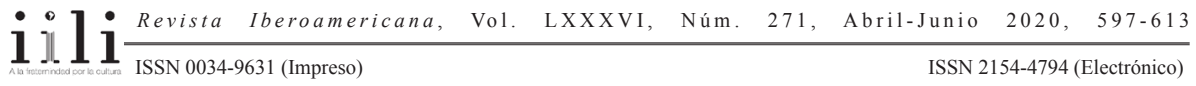


Tal Brasil, Qual Romance? Rio de Janeiro: Achiamé, 1984.

Palavras-chave: Autoritarismo; patriarcalismo; Carlos \& Carlos Sussekind; Armadilha para Lamartine

Recebido: $\quad 15$ novembro 2016

Aprovado: $\quad 15$ maio 2017 
